\title{
Electrical Impedance Tomography: Hardware Fundamentals And Medical Applications
}

Tomografía de impedancia eléctrica: fundamentos de hardware y aplicaciones médicas

Tomografia de impedância elétrica: fundamentos de hardware e Aplicações Médicas

\section{Fausto Andrés Escobar Revelo ${ }^{1}$ Víctor Hugo Mosquera Leyton ${ }^{2}$ Carlos Felipe Rengifo Rodas ${ }^{3}$}

Received: May $14^{\text {th }}, 2020$

Accepted: July $28^{\text {th }}, 2020$

Available: September $2^{\text {th }}, 2020$

How to cite this article:

F. A. Escobar Revelo, V. H. Mosquera Leyton, C. F. Rengifo Rodas, "Electrical Impedance Tomography: Hardware Fundamentals And Medical Applications," Revista Ingeniería Solidaria, vol. 16, no. 3, 2020. doi: https://doi.org/10.16925/2357-6014.2020.03.02

Artículo de investigación. https://doi.org/10.16925/2357-6014.2020.03.02

1 Department of electronics, instrumentation and control. University of Cauca. ORCID: https://orcid.org/0000-0002-5923-8051

E-mail: andresescobar@unicauca.edu.co

2 Department of electronics, instrumentation and control. University of Cauca. ORCID: https://orcid.org/0000-0003-4884-9719

E-mail: mosquera@unicauca.edu.co

3 Department of electronics, instrumentation and control. University of Cauca. ORCID: https://orcid.org/0000-0002-0601-3481

E-mail: caferen@unicauca.edu.co 


\section{Abstract}

Introduction: The following article shows a systematic review of publications on hardware topologies used to capture and process electrical signals used in Electrical Impedance Tomography (EIT) in medical applications, as well topicality of the EIT in the field of biomedicine. This work is the product of the research project "Electrical impedance tomography based on mixed signal devices", which took place at the University of Cauca during the period 2017-2019.

Objective: This review describes the operation, topicality and clinical use of Electrical Impedance Tomography systems.

Methodology: A systematic review was carried out in the IEEE-Xplore, ScienceDirect and Scopus databases. After the classification, 106 relevant articles were obtained on scientific studies of EIT systems; applications dedicated to the analysis of medical images.

Conclusions: Impedance-based methods have a variety of medical applications as they allow for the reconstruction of a body region, by estimating the conductivity distribution inside the human body; this is without exposing the patient to the damaging effects of radiation and contrast elements. Impedance-based methods are therefore a very useful and versatile tool in the treatment of diseases such as: monitoring blood pressure, detection of atherosclerosis, localization of intracranial hemorrhages, determining bone density, among others.

Originality: It describes the necessary components to design an EIT system, as well as the design characteristics depending on the pathology to be visualized.

Restrictions: The review focuses on aspects of the performance of an EIT system, depending on the pathology analyzed. Considering the hardware advances, it is possible to increase the acquisition speed (temporal resolution), thus improving the spatial resolution and the quality of the reconstructed image.

Keywords: Electrical Impedance tomography, bioimpedance, EIT medical applications.

\section{Resumen}

Introducción: En el siguiente artículo se muestra una revisión sistemática de publicaciones sobre topologías hardware utilizadas para capturar y procesar señales eléctricas utilizadas en tomografía por impedancia eléctrica (TIE) en aplicaciones médicas, así como la actualidad del TIE en el campo de la biomedicina. Este trabajo es producto del proyecto de investigación "Tomografía de impedancia eléctrica basada en dispositivo de señal mixta", que tiene lugar en la Universidad del Cauca durante el período 2017-2019.

Objetivo: Esta revisión describe la estructura hardware de los sistemas de TIE, además de sus características, como frecuencia y magnitud de señales de corriente, patrones de inyección y medición de señales y número de electrodos orientado a, uso clínico.

Metodología: Se realizó una revisión sistemática, en las bases de datos IEEE-Xplore, ScienceDirect y Scopus. Tras la clasificación se obtuvo 106 artículos relevantes sobre estudios científicos de sistemas, aplicaciones dedicadas al análisis de imágenes médicas.

Conclusión: Los métodos basados en impedancia, tienen una variedad de aplicaciones médicas, puesto que permite la reconstrucción de una región corporal, mediante la estimación de la distribución de conductividad al interior del cuerpo humano, sin radiación y elementos de contraste, tan perjudiciales para la salud de los pacientes; convirtiéndola en una herramienta muy útil y versátil en el tratamiento de enfermedades como: monitorear la presión arterial, detección de arterosclerosis, localización de hemorragias intracraneales, determinar la densidad ósea, entre otras.

Originalidad: Se describe la composición de las diversas propuestas para el diseño de sistemas TIE, así como las características dependiendo de la patología a estudiar. 
Limitaciones: La revisión se centra en aspectos de rendimiento de un sistema TIE, dependiendo de la patología a analizar. Considerando los avances Software/Hardware de esta técnica, se puede aumentar la velocidad de adquisición (resolución temporal), mejorando la resolución espacial, y la calidad de la imagen reconstruida.

Palabras clave: Tomografía de impedancia eléctrica, bioimpedancia, aplicaciones médicas TIE.

\section{Resumo}

Introdução: o a seguir mostra uma revisão sistemática das publicações sobre as topologias de hardware usadas para capturar e processar sinais elétricos usados em Tomografia de Impedância Elétrica (EIT) em aplicações médicas, bem como a actualidade do EIT no domínio da biomedicina. Este trabalho é produto do projeto de pesquisa "Tomografia de impedância elétrica baseada em dispositivos de sinais mistos", realizada na Universidade de Cauca durante o período 2017-2019.

Objetivo: esta revisão descreve o funcionamento, a atualidade e o uso clínico da tomografia de impedância elétrica sistemas.

Metodologia: Foi realizada uma revisão sistemática nas bases de dados IEEE-Xplore, ScienceDirect e Scopus. Após a classificação, foram obtidos 106 artigos relevantes sobre estudos científicos de sistemas EIT; formulários dedicado à análise de imagens médicas.

Conclusões: os métodos baseados em impedância têm uma variedade de aplicações médicas, pois permitem a reconstrução de uma região do corpo, estimando a distribuição da condutividade dentro do corpo humano; isso é sem expor o paciente aos efeitos prejudiciais da radiação e dos elementos de contraste. Métodos baseados em impedância são, portanto, uma ferramenta muito útil e versátil no tratamento de doenças como: monitoramento da pressão arterial, detecção de aterosclerose, localização de hemorragias intracranianas, determinação da densidade óssea, entre outros.

Originalidade: descreve os componentes necessários para projetar um sistema EIT, bem como as características do projeto dependendo da patologia a ser visualizada.

Restrições: A revisão enfoca aspectos do desempenho de um sistema EIT, dependendo da patologia analisado. Considerando os avanços do hardware, é possível aumentar a velocidade de aquisição (resolução temporal), melhorando assim a resolução espacial e a qualidade da imagem reconstruída.

Palavras-chave: tomografia de impedância elétrica, bioimpedância, aplicações médicas EIT.

\section{INTRODUCTION}

Electrical Impedance Tomography (EIT) is a non-invasive, radiation-free technique that supports diagnosis by medical imaging, with the extraction of information on the physiological and pathological condition of a patient's tissues and organs [1]. EIT estimates the conductivity distribution in a region through the injection of alternating current by means of an electrode array and measuring the voltages on them, managing to reconstruct images of transverse planes, which allow for analysis of pathologies in the medical field [2]. 
The processing of medical images faces several challenges such as noise, speed of signal processing and spatial and temporal resolution regarding the dimensions of the object; problems that have been addressed in different works, through the development of EIT system prototypes based on FPGA's (Field Programmable Gate Array), DSP's (Digital Signal Processing) and Microcontrollers [3,4,5]. The different proposed EIT systems have characteristics that restrict the field of application, where the potentialities of the systems designed depend on the processing device used; for example, prototypes based on FPGA's and DSP's have a higher signal processing speed, in the order of $50 \mathrm{fps}$ (frames per second), which allow for the monitoring of biological processes with high temporal variability, such as blood pressure measurement [6]. On the other hand, there are systems based on microcontrollers, which have a low frequency of frames, which allows for their incursion in biological processes of low temporal variability such as monitoring of bladder emptying and detection of cranial hemorrhages $[7,8]$.

The impedance-based methods have a variety of medical applications, since they allow for the reconstruction of a body region by estimating the distribution of conductivity inside the human body, converting it into a very useful and versatile tool in the treatment of diseases such as: monitoring blood pressure, detection of atherosclerosis, localization of intracranial hemorrhages, determining bone density, among others.

This review presents the hardware structure of EIT systems designed for medical applications, with the aim of establishing the methods that researchers use for the generation of the current signal, the definition of injection patterns and measurement of signals and demodulation, essential aspects in the design. On the other hand, the characteristics such as frame frequency, number of electrodes, current signal frequency and magnitude of current, used for medical applications, are analyzed to identify relevant aspects in the selection of devices for implementation into EIT systems.

\section{Literature Review}

\subsection{EIT Systems}

The EIT system structure, shown in Fig. 1, is composed of a direct digital synthesizer (DDS) that generates a sinusoidal voltage signal at a frequency between $2 \mathrm{~Hz}$ and 5 $\mathrm{MHz}$. This signal is the input to the current source. The current generated is directed towards a switching block which injects the current through boundary electrodes on the object under study. The potential generated by the current is then measured 
by an amplification stage that can be differential or referenced to ground. The measured potential is demodulated in order to extract the magnitude and phase of the voltage signal. These modules must be synchronized with the signal generator so that the magnitude and phase of the signal at the time of being measured is correct. Finally, the conductivity is processed through an EIT image reconstruction algorithm [5], [9], [10].

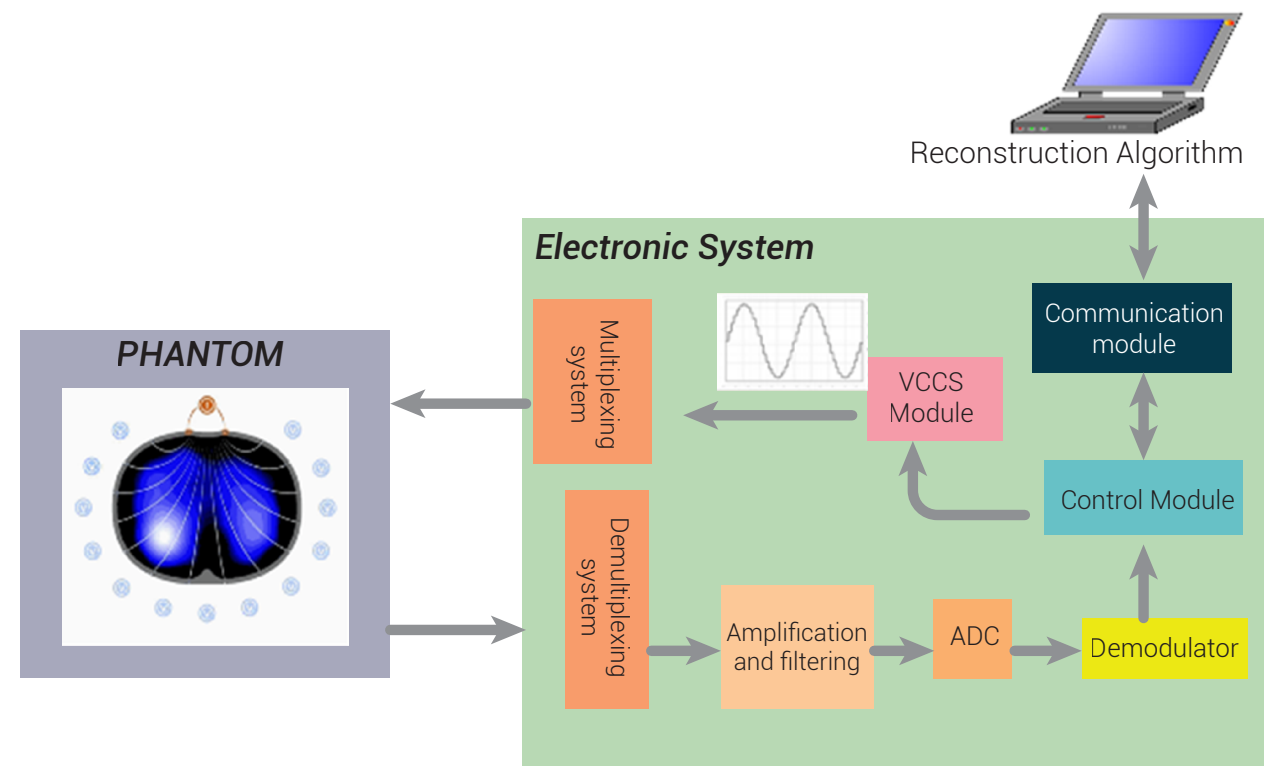

Figure. 1 EIT systems scheme.

Source: own work

The use of EIT systems in medicine for the diagnosis of pathologies, such as the analysis of intrapulmonary gas distribution, evaluation of pulmonary ventilation in patients with chronic obstructive pulmonary disease (COPD), blood pressure monitoring, location of intracranial bruising, vesicoureteral reflux or determining bone mineral density (BMD), among others, shows promising results; especially where the electrical characteristics of the tissues or organs under observation allow the EIT to determine pathologies. In the field of medical applications, EIT system characteristics such as injection and measurement patterns, geometric arrangement and number of electrodes [11], [12], in addition to the frame rate, are relevant [13]-[15]. Below are ElT works regarding the monitoring and detection of various pathologies and the characteristics defined for the EIT systems used [11]. 


\subsection{Electrode arrays}

A single ring array, with 16 electrodes, is the most common feature used in EIT medical applications; although other research in the field of pulmonary ventilation, presenting good results, employs double ring arrangements for a better EIT analysis [16]. In urodynamic studies, different configurations such as single ring, double ring, planar and vertical ring have been used, showing that ring arrangements have a reduced sensitivity compared to matrix and vertical arrangements [17]. Studies of the cranial cavity have used semicircular arrangements, allowing for the detection of intracranial hemorrhages [18]. The previous studies reveal the importance of the analysis of the EIT electrode configuration in the monitoring and detection of various pathologies, an important aspect to be evaluated for the design of EIT systems.

\subsection{Injection and measurement patterns}

The adjacent injection and measurement patterns method is the most commonly used in EIT medical applications. Silva and his colleagues [19], in their work, study the influence of injection and measurement patterns on EIT, concluding that it is not possible to generalize which is the best pattern for reconstruction of EIT images. This implies a study of this characteristic, according to the oriented application of EIT.

The choice of injection and measurement patterns depends on whether the system will make use of the variations in frequency in the measurement of electrical potential on the phantom; EIT systems are subdivided into mono-frequency or multi-frequency [20]. Mono-frequency systems make use of a current signal at a single frequency in the $100 \mathrm{kHz}$ range, measuring the real part of the voltage. The multi-frequency systems inject a current signal at different frequencies, obtaining the real and imaginary voltage part, increasing the error in the measurements due to the parasitic capabilities of the multifrequency. Therefore, when using different electrode configurations for current injection and voltage measurement, this is known as the tetra-polar configuration, which was developed by Brown and Seagar in the MarkSheffield project in 1987 [19], [21]. One of the methods is that of adjacent electrodes Fig 2a, which uses pairs of adjacent electrodes for current injection, and measures the voltage for the remaining 14 electrodes. This provides 13 voltage measurements, rotating through the 8 pairs of electrodes in the form of a ring, getting 208 measurements that will be used to reconstruct conductivity [22]. The polar configurations 2c and quasi-polar 2d, use electrodes defined for current injection and for voltage measurement. As the current density is at the center of the object, it generates a more homogeneous spatial resolution [23], [24]. 


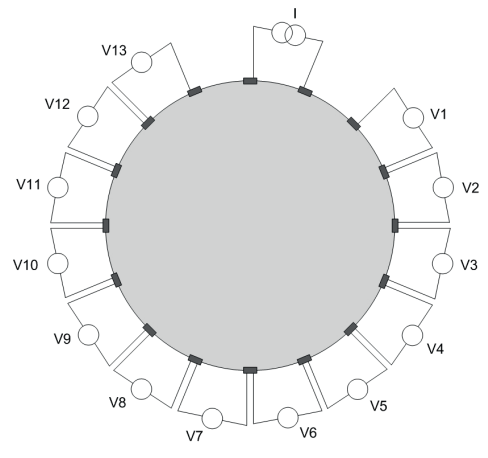

a) Adjacent

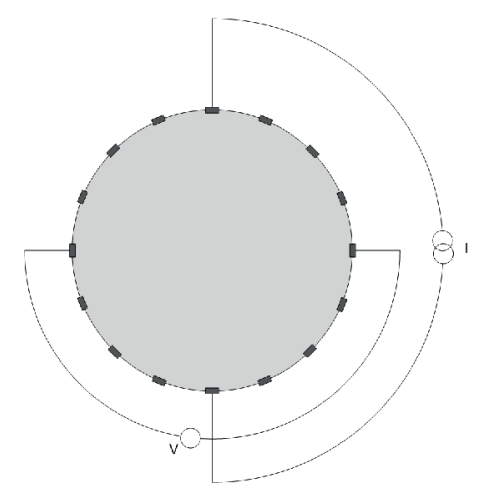

c) Polar

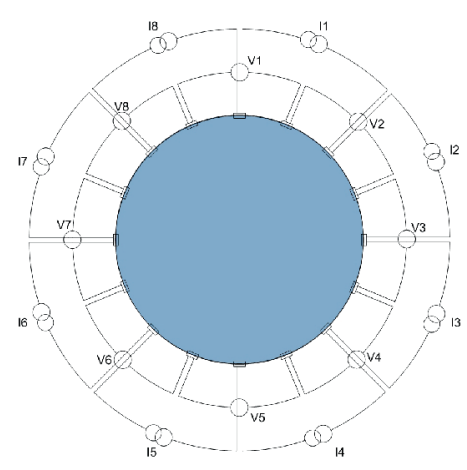

b) Crossed

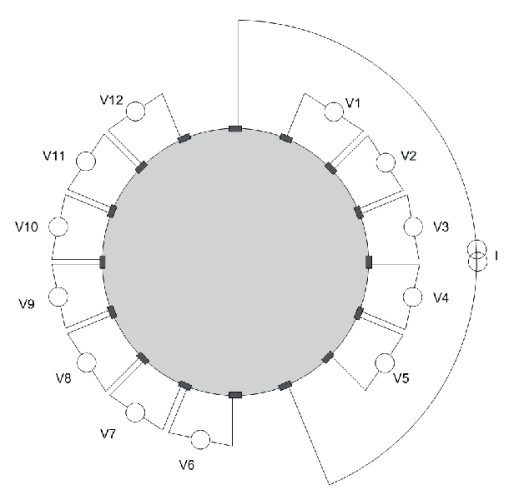

d) Quasi-polar

Figure. 2. Electrode configurations for an EIT system.

Source: Adapted from [25].

\section{Methodology}

A systematic review was carried out using the methodology proposed in [26], focusing on hardware and medical applications of EIT systems.

3.1 Search Strategies: First, a search was conducted in the IEEE-Xplore, ScienceDirect and Scopus databases. This search is based on a series of inquiry questions, an analysis and classification of the literature. To perform the search, chains such as: Algorithm AND Image AND Tomography, Processing AND Image AND Tomography, Pulmonary AND Impedance AND Tomography, Electrical AND Impedance AND Tomography AND Hardware were used.

3.2 Inclusion and exclusion criteria: Subsequently, some papers were discarded due to restrictions such as: gray literature, publication date (2012-present), journal 
classification, low added value. These criteria were applied after reading the abstracts of the papers found through the search chains.

3.3 Data extraction: The systematic review found 628 works; 107 studies, relevant to the objective of this review, were left after applying the exclusion criteria mentioned above.

3.3 Data analysis: Subsequently, the selected articles were studied to identify the hardware characteristics of the EIT systems and the requirements of those systems in medical applications.

\section{RESULTS}

Investigations have been made around the development of the EIT system, such as the PULMOVISTA 500 commercial system of the Dräger company, which uses a 16-electrode topology for injection and measurement of signals using the "adjacent" method and has the capacity to generate up to 50 frames per second (fps); this is used in the monitoring of the complete ventilation cycle in real time [27], [28]. The Maltron Sheffield Mark system, designed by Brown and Seagar in 1987, is an EIT system consisting of 16 electrodes that has been in development for 20 years. Like the PULMOVISTA 500, it uses an adjacent injection and measurement pattern. Its later versions, the Mark I and Mark 2.5 systems, include a self-calibration system of the voltage injection source along with other modules that provide great performance but lead to a more complex system [29], [30]. Other systems such as OXBACT-5 [31] and Darmouth [32] consist of 64 electrodes and use the adjacent method for excitation and measurement. These systems, as can be evidenced, are restricted to a single method of current injection and measurement of potentials, limiting the image reconstruction process [33].

Other EIT systems have been developed by different researchers (see Table 1). For the most part, the proposed systems have FPGA-based architectures, as this technology provides the necessary characteristics for application in biological processes of high temporal variability. This is because FPGA allows for the implementation of several of the modules of the EIT system, such as the direct digital synthesizer (DDS) and the A/D and D/A converters, reducing hardware and interfaces between modules, facilitating their implementation and generating a performance similar to commercial systems in terms of frame rate.

The systems in Table 1 have been evaluated considering the characteristics of the biological process to be monitored, although few present in-vivo tests. For example, in [34] the proposed system generates $131 \mathrm{fps}$ by means of 16 surface electrodes, 
measuring the heart rate in healthy patients. In addition, it reconstructs the images of conductivity distribution of the thoracic cage, clearly differentiating the cross section of the lungs and heart. The injection and measurement method used in the tests is of the "adjacent" type. Another study is that presented by Shi and his colleagues [35]. They designed an EIT system with 16 electrodes that generates $1 \mathrm{fps}$, making it possible to determine the alterations in the brain caused by temporary occlusion in the unilateral carotid artery.

Other prototypes based on FPGA's are in the stage of testing, using them on phantoms to characterize them and evaluate their potential in medical applications, such as the system presented in [5] which generates $100 \mathrm{fps}$ with 32 electrodes and uses the adjacent injection and measurement method to reconstruct conductivity distribution images within a phantom with saline solution. The limitation of this system is the need of National Instruments hardware for its implementation, which impacts on costs. Another system tested on phantoms is the one presented by Artem and his colleagues [36], which does not depend on a proprietary data acquisition system, as in the system mentioned above, and consists of 16 electrodes for signal injection and measurement. Both works only present results using the adjacent injection and measurement method.

The DSP's (Digital Signal Processor) are another alternative for the development of EIT systems in [37] and [30]; the first system has the capacity to manage 128 electrodes, the second system obtains $100 \mathrm{fps}$ with 8 surface electrodes. Both proposals are evaluated using phantoms and employ the adjacent method in injection and measurement. A differentiating element in the system developed by Wi and his colleagues [30] is the ability to reconfigure the injection and measurement pattern between the methods adjacent and polar. This gives more versatility to the system. The implementation of EIT systems with DSP implies the use of a greater number of electronic components, compared to those implemented with FPGA's, which makes it difficult to connect and implement.

Table 1. HARDWARE CHARACTERISTICS OF EIT SYSTEMS.

\begin{tabular}{|c|c|c|c|c|c|}
\hline Reference & Main module & $\begin{array}{l}\text { Signal } \\
\text { generator } \\
\text { method }\end{array}$ & $\begin{array}{c}\text { Signal } \\
\text { Reading card }\end{array}$ & $\begin{array}{c}\text { Discrete } \\
\text { components }\end{array}$ & $\begin{array}{c}\text { Frequency } \\
\text { range }\end{array}$ \\
\hline Santos S [34]. & Virtex-6 FPGA & $\begin{array}{l}\text { Direct Digital } \\
\text { Synthetizer (DDS) } \\
\text { Compiles v5,0 }\end{array}$ & $\begin{array}{l}\text { Virtex-6 FPGA } \\
\text { DSP Kit con AD/ } \\
\text { DA }\end{array}$ & --- & $60-960 \mathrm{kHz}$ \\
\hline
\end{tabular}


(viene)

\begin{tabular}{|c|c|c|c|c|c|}
\hline Reference & Main module & $\begin{array}{l}\text { Signal } \\
\text { generator } \\
\text { method }\end{array}$ & $\begin{array}{c}\text { Signal } \\
\text { Reading card }\end{array}$ & $\begin{array}{c}\text { Discrete } \\
\text { components }\end{array}$ & $\begin{array}{c}\text { Frequency } \\
\text { range }\end{array}$ \\
\hline Shi X [35] & FPGA & --- & $\begin{array}{l}\text { ADC Module (NI } \\
\text { 5751), (AD9252), } \\
\text { signal condition- } \\
\text { er (THS 7002TI) }\end{array}$ & VCCS (AD844) & $1-190 \mathrm{kHz}$ \\
\hline Khan S [5]. & $\begin{array}{l}\text { FPGA NI Rio } \\
7952 R \text {, Vitex } \\
\text { 5LX50 }\end{array}$ & $\begin{array}{l}\text { (NI 5406), } \\
\text { synchronizer NI } \\
6674 t\end{array}$ & $\begin{array}{l}\text { DAC DRIVER/ADC } \\
\text { DRIVER }\end{array}$ & $\begin{array}{l}\text { Relay Control NI } \\
\text { XSeries } \\
6341 \text { ADG732 } \\
\text { (multiplexer) }\end{array}$ & \\
\hline Artem [36]. & $\begin{array}{l}\text { FPGA Cyclone II } \\
\text { Family }\end{array}$ & $\begin{array}{l}\text { NCO (numeri- } \\
\text { cally controlled } \\
\text { oscillator) } \\
\text { M4K block SIN/ } \\
\text { COS }\end{array}$ & $\begin{array}{l}\text { ADC modules } \\
\text { (NI5751) }\end{array}$ & --- & $10-100 \mathrm{kHz}$ \\
\hline Khan S [103] & $\begin{array}{l}\text { FPGA (NI Flex Rio } \\
7952 R)\end{array}$ & $\begin{array}{l}\text { NI } 540614 \text { bits, } \\
\text { synchronizer } \\
\text { (NI6674t) }\end{array}$ & $\begin{array}{l}\text { AMP (AD8250), } \\
\text { ADC (AD7367) }\end{array}$ & $\begin{array}{l}\text { (NI X-Series Card } \\
6341 \text { ) }\end{array}$ & \\
\hline Zhang Z [104] & $\begin{array}{l}\text { FPGA Cyclone II } \\
\text { Family }\end{array}$ & AD 9852 & $\begin{array}{l}\text { EP3C10F256C8N } \\
\text { FPGA }\end{array}$ & PCI 9054, PCI9052 & \\
\hline Zeng Y [91] & $\begin{array}{l}\text { FPGA Cyclone II } \\
\text { Family }\end{array}$ & $\begin{array}{l}\text { DDS } \\
\text { (TMS320F2812) }\end{array}$ & $\begin{array}{l}\text { ADC (AD9235), } \\
\text { ROM(EPCS4), } \\
\text { DAC (AD9783) }\end{array}$ & $\begin{array}{l}\text { ADC } 12 \text { bits, DAC } \\
14 \text { bits }\end{array}$ & $10 \mathrm{~Hz}-250 \mathrm{kHz}$ \\
\hline Wi H [105] & $\begin{array}{l}\text { DSP } \\
\text { (TMS320F2812) }\end{array}$ & $\begin{array}{l}\text { EP3C10F256C8N } \\
\text { FPGA }\end{array}$ & $\begin{array}{l}\text { AD624 (Pre-am- } \\
\text { plifier) MAX } 275 \\
\text { (Butterworth) }\end{array}$ & $\begin{array}{l}\text { Port } \\
\text { (DS1267E-010), } \\
\text { switches (MAX- } \\
\text { 4545CAP1009), } \\
\text { source (EC- } \\
\text { M100US07, } \\
\text { ECM 100US09) }\end{array}$ & $1 \mathrm{~Hz}-50 \mathrm{kHz}$ \\
\hline Xu G [37] & $\begin{array}{l}\text { DSP } \\
\text { (TMS320F2812 TI) }\end{array}$ & AD852 & $\begin{array}{l}\text { AD624 (Pre-am- } \\
\text { plifier) MAX } 275 \\
\text { (Butterworth) }\end{array}$ & $\begin{array}{l}\text { MAX306 CPLD } \\
(\text { EPM1270) }\end{array}$ & $0.1 \mathrm{~Hz}-1 \mathrm{MHz}$ \\
\hline $\begin{array}{l}\text { Kukharenko } \\
{[106]}\end{array}$ & PSoC (CY8C58LP) & $\begin{array}{l}\text { Comparison and } \\
\text { amplification } \\
\text { modules integrat- } \\
\text { ed in PSoC. }\end{array}$ & ADC 12 bits PSoC & --- & $100 \mathrm{~Hz}-1 \mathrm{MHz}$ \\
\hline Fouchard A [38] & Raspberry Pi & DDS(AD9837) & $\begin{array}{l}\text { ADC (ADS7947), } \\
\text { buffer (LMV651, } \\
\text { to output } \\
\text { DDS), Current } \\
\text { sensor (OPA380), } \\
\text { measure } \\
\text { voltage (SR560) }\end{array}$ & Redd Relays & $0.1 \mathrm{~Hz}-1 \mathrm{MHz}$ \\
\hline Chitturi V. [107] & Arduino Mega & $\begin{array}{l}\text { Generator IC } \\
\text { ICL8038 }\end{array}$ & Amp (TL071 OPA) & Mux (CD4067B) & $1-60 \mathrm{kHz}$ \\
\hline Huang J [39] & $\begin{array}{l}\text { Microprocessor } \\
\text { (MSP 430) }\end{array}$ & Microprocessor & --- & $\begin{array}{l}\text { Demodulator } \\
\text { AD630 }\end{array}$ & $10 \mathrm{~Hz}-200 \mathrm{kHz}$ \\
\hline Khalighi M [40] & $\begin{array}{l}\text { Microprocessor } \\
\text { Atmega } 128\end{array}$ & $\begin{array}{l}\text { XR-2206 (EXAR } \\
\text { Inc) }\end{array}$ & $\begin{array}{l}\text { LF412 IC, AD844, } \\
\text { LM393, AD844, } \\
\text { ADC } \\
\text { (AD1674), AD625. }\end{array}$ & $\begin{array}{l}\text { LF412, 74HC4053, } \\
\text { AD625JNZ, } \\
\text { TC408tBP, } \\
\text { ADG506AKN. }\end{array}$ & $10 \mathrm{~Hz}-1 \mathrm{MHz}$ \\
\hline
\end{tabular}

Source: own work 
The adjacent injection and measurement method, without option to re-configure patterns, is the most frequently studied system. This makes it difficult to analyze the effect when using others patterns of the reconstruction process. This void is faced by Fouchard and his colleagues [38], who designed a system that allows for the reconfiguration of injection and measurement patterns through a switching matrix consisting of electronic relays managed by a Raspberry PI. The system has the limitation of generating a frame every 45 seconds, well below the $1 \mathrm{fps}$ frame rate required for the monitoring of biological processes. Another of its limitations is that the system only works offline. In [39], another EIT system based on a microprocessor can be observed, which consists of 16 channels that, unlike the prototype presented in [38], manages to reconstruct the cross-section of the rib cage of living beings, differentiating between the distribution of conductivity of the lungs without an alternative reconfiguration system in the patterns of injection and measurement. Another EIT system proposal is the one presented in [40], whose purpose is the detection of cancer. It consists of a phantom tank with an array of 16 electrodes with an adjacent injection pattern, using Arduino-one as the main module. Prototypes based on microcontrollers require external devices such as DDS modules, voltage controlled current sources, switching systems, demodulators, etc. This limits these architectures due to the frequency response characteristics of the elements that compose them, along with a low frame rate. To verify the EIT system's performance, a saline tank is used, with electrical conductivity emulating that of a homogeneous region or medium containing tissue such as the bladder, skull or rib cage. In the center is a small plastic cylinder of lower conductance that resembles the organ to be analyzed such as a lung $(12.5 \Omega \mathrm{m})$, blood (1.4 -1.7 $\Omega \mathrm{m})$, liver $(8.3 \Omega \mathrm{m})$ or radial bone $(160 \Omega \mathrm{m})$, and by means of the injection and measurement of the current and potential, because the conductivity in the analyzed region decreases, the change of resistance values is obtained. The number of electrodes used in the injection and measurement can influence the spatial and temporal resolution, as well as the number of frames and SNR of the reconstructed image [11], [12]. Therefore, the EIT systems use 8 to 16 electrodes, with an injection current between $30 \mu \mathrm{A}$ and $5 \mathrm{~mA}$ at frequencies of $10 \mathrm{~Hz}$ to $5 \mathrm{MHz}$, depending on the region analyzed.

\subsection{Medical applications of EIT}

Current applications of medical images with EIT include: the analysis of intrapulmonary gas [41], [42], monitoring blood pressure [43], detection of intracranial hemorrhages [44], [45], resuscitation of volume of bladder urine [46], [47], establishing bone density [48], cardiac minimization after cardiac arrest [49]. Then, the pathologies 
covered by EIT by intra-corporeal region are analyzed. The most relevant medical applications in which the EIT presents promising results are detailed below.

\subsubsection{The Respiratory System:}

One of the most studied organs by EIT is the lung. In Table 2, it is possible to observe different works related to this organ and the characteristics used by the EIT system in the development of the respective study. It is evident that many of the works do not present precise information on the characteristics used for the study, especially those that perform tests on humans. This is due to the use of a commercial system called PulmoVista 500, or its predecessors Sheffield Mark I or GOE MF II, developed in 1980 and 1990 respectively, and it is inferred that they used the maximum benefits offered by this equipment. For example, the PulmoVista system has the capacity to generate up to 50 frames per second, using a ring of 16 electrodes, with a current injection of $1 \mathrm{~mA}$. The investigations of EIT in the field of the respiratory system can be divided into two:

4.1.1.1 Pathology Oriented: These works employ EIT systems previously developed by other researchers or commercial systems and focus on in-vivo applications. In [50]-[56] for example, pulmonary ventilation under anesthesia, mechanical ventilation, embolism and pulmonary edema detection are analyzed and monitored in animals, to evaluate and monitor the pathology under analysis. This is then brought over to human applications. The results obtained in these works present a high accuracy in the reconstruction of the images that support the medical diagnosis. On the other hand, there are works such as [57]-[60], in which this technology is applied to a population of patients with the pathologies listed above, confirming the feasibility of making EIT a valid technique in processes of detection and monitoring of pulmonary pathologies.

Table 2. Characteristics of EIT in lung applications.

\begin{tabular}{lccccc}
\hline \multicolumn{1}{c}{ Pathology } & $\begin{array}{c}\text { Number of } \\
\text { electrodes }\end{array}$ & $\begin{array}{c}\text { Frequency } \\
\text { (kHz) }\end{array}$ & SNR & $\begin{array}{c}\text { Current } \\
\text { (mA) }\end{array}$ & $\begin{array}{c}\text { Frames } \\
\text { (fps) }\end{array}$ \\
\hline Analysis of intrapulmonary gas distribution [50] & 16 & -- & -- & --- & -- \\
\hline $\begin{array}{l}\text { Evaluation of the effects of non-invasive venti- } \\
\text { lation during spontaneous breathing [57] }\end{array}$ & 16 & -- & -- & -- \\
\hline Lung impedance distribution measurement [39] & 16 & $10-200$ & --- & -- & - \\
\hline
\end{tabular}


(viene)

\begin{tabular}{|c|c|c|c|c|c|}
\hline Pathology & $\begin{array}{l}\text { Number of } \\
\text { electrodes }\end{array}$ & $\begin{array}{l}\text { Frequency } \\
\qquad(\mathbf{k H z})\end{array}$ & SNR & $\begin{array}{l}\text { Current } \\
(\mathrm{mA})\end{array}$ & $\begin{array}{c}\text { Frames } \\
\text { (fps) }\end{array}$ \\
\hline $\begin{array}{l}\text { Measurement of pulmonary impedance } \\
\text { distribution [34] }\end{array}$ & 16 & $60-960$ & 106.9 & & $<131$ \\
\hline Inhomogeneity detection of ventilation [50] & 16 & --- & ---- & --- & --- \\
\hline $\begin{array}{l}\text { Mechanical ventilation distribution monitoring } \\
\text { [51] }\end{array}$ & 16 & 50 & -- & 50 & 13 \\
\hline $\begin{array}{l}\text { Pulmonary recruitment and endotracheal } \\
\text { suction in ventilated premature infants [58] }\end{array}$ & 16 & --- & -- & -- & 44 \\
\hline $\begin{array}{l}\text { Evaluation of pulmonary ventilation in neo- } \\
\text { nates [61] }\end{array}$ & 8 & $4-812.75$ & -- & -- & 25 \\
\hline $\begin{array}{l}\text { Air distribution evaluation in preterm infants } \\
\text { [62] }\end{array}$ & 16 & 50 & --- & --- & --- \\
\hline Lung ventilation monitoring [63] & 32 & ---- & --- & --- & 20 \\
\hline Tidal Volume Monitoring [64] & 16 & 48 & --- & 1 & 17 \\
\hline $\begin{array}{l}\text { Evaluation of the level of instability of bron- } \\
\text { chopulmonary dysplasia [65] }\end{array}$ & 16 & $2-1600$ & --- & 1.5 & 25 \\
\hline Real-time lung ventilation monitoring [66] & 32 & $10-200$ & --- & 0.1 a 1 & 20 \\
\hline Lung impedance distribution monitoring [67] & 32 & $10-200$ & 56.3 & 0.1 a 1 & 20 \\
\hline Lung function monitoring [68] & 32 & $10-200$ & -- & $0.1-8$ & 30 \\
\hline Pulmonary embolism detection [52] & 32 & 100 & --- & 5 & 10 \\
\hline Pulmonary congestion classification [69] & 5 & --- & --- & --- & --- \\
\hline $\begin{array}{l}\text { Baseline selection for pulmonary impedance } \\
\text { distribution [53] }\end{array}$ & 16 & 110 & -- & 9 & 50 \\
\hline $\begin{array}{l}\text { Evaluation of pulmonary ventilation in pa- } \\
\text { tients with COPD [59] }\end{array}$ & 16 & 50 & --- & 5 & 33 \\
\hline $\begin{array}{l}\text { Pulmonary ventilation study in different } \\
\text { patient positions [54] }\end{array}$ & 32 & 144 & --- & 3 & 30 \\
\hline Pulmonary Function Evaluation [70] & 16 & --- & --- & --- & --- \\
\hline 3D lung function monitoring [60] & 16 & 90 & --- & 5 & 40 \\
\hline Quantification of pulmonary edema [55] & 32 & --- & ---- & ---- & 50 \\
\hline
\end{tabular}

Source: own work

4.1.1.2 EIT System Orientated: In [39], [61], [66], [68], [71], [72], systems developed by researchers oriented to pulmonary applications are evaluated. These works detail the development and hardware characteristics; their results are based on tests using phantoms, and sometimes on healthy volunteers. This strategy seeks to validate that the developed system complies with the requirements for the diagnosis and monitoring of pathologies, to project it as a future commercial alternative for medical applications.

Other pathologies, such as tumors and lung cancer, have been the subject of study. Yang and his colleagues [73], for example, were able to monitor lung tumors through image reconstruction, and in [74], a study of healthy and lung cancer tissue is 
presented. It is concluded that it is possible to detect and differentiate the two types of tissue using electrical impedance, expanding the field of exploration of EIT systems for the diagnosis of cancer.

According to the literature, the study of the pulmonary system requires high performance from the EIT system, due to the high frequency of frames necessary to analyze medical pathologies. This leads to high hardware characteristics, necessary for the processing of the collected signals, increasing the cost of the system.

\subsubsection{Blood vessels}

Hemodynamic system monitoring is a necessity in following the evolution of a patient. EIT technology has ventured into this topic, allowing continuous measurement of hemodynamic parameters in a non-obstructive and non-invasive manner [75], [76]. One of the first experiments in pigs shows that this technique is a good candidate for the development of a new family of continuous non-invasive blood pressure monitors [77]. A characteristic to highlight the EIT system used in this work is the generation of $50 \mathrm{fps}$, which calls for the system to include high performance hardware, such as that required in the pulmonary system. In [78], [79] there are tests of EIT on humans; the first in the measurement of systolic volume and the second in the detection of atherosclerosis. Both works show satisfactory results, despite the poor resolution of the images due to the use of 16 electrodes, unlike the 32 used by Sola and his colleagues in [77]. To monitor the pulmonary artery pressure through the use of a ring of 16 electrodes, Proença and his colleagues [6], [80] achieved, with 25 fps, estimates of blood pressure by measuring the pulse transit time. These works highlight the potential of EIT in this field. The in-vivo advances shown in [80] generate an opportunity to develop EIT systems with less demanding characteristics and good results. However, the methods based on the observation of the time series of certain pixels or regions, derived from the behavior of the impedance with the movement of the fluids (perfusion, breathing), intrinsically require high speed and high resolution simultaneously.

\subsubsection{Brain}

Miscellaneous investigations have been conducted to determine the impedance of head tissues with the aim of diagnosising and monitoring brain edemas and intracranial hemorrhages in both animal and human models, as well as in-vitro models that are waiting to be validated. Table 3 shows the different works that have been carried out using EIT in this field. In these, the number of electrodes is a highlighted aspect for 
which there is no evidence of a consensus for the same pathology. For the number of frames per second, the researchers mostly agree on using one frame per second in their studies, which decreases the processing characteristics in the design of EIT systems. Concerning the current signal frequency and its amplitude, they are adjusted to the normativity for medical equipment; $50 \mathrm{kHz}$ and $1 \mathrm{~mA}_{\mathrm{p}-\mathrm{p}}$. The in-vivo advances presented in [7], [35], [81]-[84], show the feasibility of using EIT in monitoring brain activity and detecting and monitoring cranial hemorrhages. Although the results help detect the change in terms of impedance of cerebral fluids, there are still aspects to explore in this field, such as optimal number and arrangement of electrodes and image reconstruction algorithms.

Table 3. Characteristics of EIT in brain applications.

\begin{tabular}{lccccc}
\hline \multicolumn{1}{c}{ Phatology } & $\begin{array}{c}\text { Number of } \\
\text { electrodes }\end{array}$ & $\begin{array}{c}\text { Frequency } \\
\text { (kHz) }\end{array}$ & $\begin{array}{c}\text { SNR } \\
\text { (dB) }\end{array}$ & $\begin{array}{c}\text { Current } \\
\text { (mA) }\end{array}$ & $\begin{array}{c}\text { Frames } \\
\text { (Fps) }\end{array}$ \\
\hline Location of intracranial hematoma [18] & 8 & 50 & -- & 1 & -- \\
\hline Cerebral Edema Monitoring [81], [82] & 16 & 50 & 80 & 1 & 1 \\
\hline $\begin{array}{l}\text { Determination of the impedance of intra- } \\
\text { cranial tissues [85] }\end{array}$ & 6 & 25 & -- & 0.14 & --- \\
\hline Focal monitoring of cerebral infarction [73] & 16 & 50 & --- & 1 & 1 \\
\hline Brain activity monitoring [7] & 30 & 1.7 & -- & 1 & --- \\
\hline Brain activity monitoring [35] & 16 & 50 & 83 & 1 & 1 \\
\hline Intracranial hemorrhage detection [83] & 32 & 10 & --- & --- & 20 \\
\hline
\end{tabular}

Source: own work

\subsubsection{Bladder}

The so-called vesicoureteral reflux, is a pathology that involves the leakage of urine from the bladder to the kidneys. This pathology can generate chronic renal failure, urinary tract infections, kidney infection, nephrotic syndrome, scarring of the kidneys, etc. For this reason, EIT seeks to monitor the bladder volume and support the diagnosis of this pathology. In the case of Li et al. [86], who designed an EIT system based on 16 electrodes, with a frequency range of 0 to $12.5 \mathrm{MHz}$, they managed to reconstruct the distribution of impedance in the bladder, and so establish a close relationship between bladder volume and estimated conductivity in healthy patients. On the other hand, Schlebusch and collaborators [87], [88], with the aim of supporting paraplegic patients suffering from the sensation of a decreased bladder volume sensation due to damage to their neuronal structures, used EIT to monitor the bladder volume. The 
in-vitro experiments carried out in this work used a planar arrangement of $64(8 \times 8)$ electrodes, unlike the classic ring arrangements. A feature to highlight in this application, is the need for 1 frame per second, to determine the bladder emptying. These results demonstrate an opportunity to make contributions using EIT in this field.

\subsubsection{Osseous System}

Osteoporosis is another disease in which EIT has dabbled, by determining bone mineral density (BMD); it was used in [89] to estimate the degree of osteopenia. This study focused on in-vitro tests, obtaining very good results, though due to the physiological characteristics of future patients, this technique would present inaccuracies in estimations. In [33], it was possible to identify the change in pelvic density when applying a current with a frequency of $100 \mathrm{kHz}$ to the patient. The experiments developed in this work demonstrated that it is possible to measure the bone mineral density via EIT, helping to define the seriousness of osteopenia of male patients; a field of exploration remains regarding women due to their physiological characteristics requiring a different model for the estimation of BMD.

Bone impedance can also become a support for forensic science, as it can help determine the time of death of an individual, as concluded in [90], which, by measuring the electrical bioimpedance of the femur or tibia and the height of the subject, it is possible to set the time of death more accurately. It is important to note that the number of electrodes used in these case studies is small; 5 electrodes in the first case and 2 in the second.

\section{DISCUSSION}

The review carried out in this article demonstrates the potentiality of electrical impedance tomography due to its evolution through technical advances. The development of a high speed and high resolution tomography system is usually performed by experts on the subject. On the other hand, research based on high performance tomography is usually focused on the pathology diagnostics capacity and employs commercial equipment. In addition, the works that are based on the development of high-performance tomography are oriented to the design and testing of modules of said equipment and do not show a complete development due to its complexity.

Therefore, with EIT being a technology that is not easily accessible, the medical industry has ventured into the development of EIT equipment. It has shown good performance in the study of medical pathologies related to the respiratory and gastric 
systems, like the Sheffield Mark equipment manufactured by Maltron, which has more than 20 years of research in the field of EIT [91]-[93]; likewise Dräger Medical with the Pulmovista 500 [94], [95].

These investigations have evidenced that the spatial and temporal resolution, the frequency of frames, and the geometric arrangement of the electrodes have an important role with regards to information extraction in medical images. Other aspects to consider are noise and irregularities due to the anatomical structure of the human body [96]; this is as EIT systems guide their designs to meet these challenges. The EIT prototypes proposed by the scientific community are integrated with analog components and control devices [97], especially used in the processes of signal generation, measurement and processing. This is how proposals are based on FPGA [5], [34], [36], [98], [99], DSP [91], [100] and Microcontrollers [39], [40], which present modular architectures. Although they have sufficient characteristics for particular medical applications, these proposals have limitations such as the calibration of the modules for generating sinusoidal signals, reconfiguration of injection patterns and measurement of signals, which may require a hardware reconfiguration [101], [102].

Consequently, it is very important to continue the exploration of new technologies that help in the efficiency of EIT systems. This will create a better scenario for the use of this technique in the analysis of medical images, providing reliability, efficiency and low cost.

\section{CONCLUSION}

Electrical impedance tomography has ventured into various medical applications, showing good results. This has led to research groups around the world focusing on the development of EIT systems that meet the requirements of the medical field. The developments found in this review show that the advances in analog and digital electronics have allowed for the development of low-cost prototypes with the necessary features for the study of tissues and organs. On the other hand, the use of current signals of $1 \mathrm{~mA}$ at frequencies of $50 \mathrm{kHz}$, are the characteristics most used in EIT for monitoring of biological processes and tissues. Also, the number of electrodes greatly improves the spatial resolution of the images, resulting in a better operation of this technique; especially in processes with high temporal variability. 


\section{References}

[1] L. A. Geddes and L. E. Baker, "The specific resistance of biological material-A compendium of data for the biomedical engineer and physiologist," Medical and biological engineering, vol. 5, no. 3. pp. 271-293, 1967. [Online]. doi: 10.1007/BF02474537.

[2] H. Wang, H. Hu, L. Wang, and H. Wang, "Image reconstruction for an Electrical Capacitance Tomography (ECT) system based on a least squares support vector machine and bacterial colony chemotaxis algorithm," Flow Measurement and Instrumentation, vol. 27. pp. 59-66, 2012. [Online]. doi: https://doi.org/10.1016/j.flowmeasinst.2012.05.006.

[3] H. Sohal, H. Wi, A. L. McEwan, E. J. Woo, and T. I. Oh, "Electrical impedance imaging system using FPGAs for flexibility and interoperability," BioMedical Engineering OnLine, vol. 13. 2014. [Online]. doi: 10.1186/1475-925X-13-126.

[4] S. Liu, X. Deng, Z. Jiang, and Y. Tang, "Hardware Design of Tuber Electrical Resistance Tomography System Based on the Soil Impedance Test and Analysis," MATEC Web of Conferences, vol. 68, p. 12008, Aug. 2016. [Online]. doi: 10.1051/matecconf/20166812008.

[5] S. Khan, P. Manwaring, A. Borsic, and R. Halter, "FPGA-based voltage and current dual drive system for high frame rate electrical impedance tomography," IEEE Transactions on Medical Imaging, vol. 34, no. 4. pp. 888-901, 2015. [Online]. doi: 10.1109/TMI.2014.2367315.

[6] M. Proenca et al., "Non-invasive monitoring of pulmonary artery pressure at the bedside," in 2016 38th Annual International Conference of the IEEE Engineering in Medicine and Biology Society (EMBC), 2016, pp. 4236-4239. [Online]. doi: 10.1109/EMBC.2016.7591662.

[7] K. Y. Aristovich, B. C. Packham, H. Koo, G. S. dos Santos, A. McEvoy, and D. S. Holder, "Imaging fast electrical activity in the brain with electrical impedance tomography," Neurolmage, vol. 124, no. Pt A. pp. 204-213, 01-Jan-2016. [Online]. doi: 10.1016/j.neuroimage.2015.08.071.

[8] C. Li, S. Balla-Arabé, and F. Yang, "Embedded multi-spectral image processing for real-time medical application," Journal of Systems Architecture.

[9] Guizhi Xu et al., "The Acquisition Hardware System with Direct Digital Synthesis and Filtered Back-Projection Imaging in Electrical Impedance Tomography," 2005 IEEE Engineering in Medicine and Biology 27th Annual Conference. pp. 7758-7761, 2005. [Online]. doi: 10.1109/ IEMBS.2005.1616311. 
[10] T. A. Khan and S. H. Ling, "Review on electrical impedance tomography: Artificial intelligence methods and its applications," Algorithms, vol. 12, no. 5, 2019. [Online]. doi: 10.3390/ a12050088.

[11] A. Adler, P. O. Gaggero, and Y. Maimaitijiang, "Adjacent stimulation and measurement patterns considered harmful," Physiological Measurement, vol. 32, no. 7, pp. 731-744, Jul. 2011. [Online]. doi: 10.1088/0967-3334/32/7/S01.

[12] D. C. Barber and A. D. Seagar, "Fast reconstruction of resistance images," Clinical Physics and Physiological Measurement, vol. 8, no. 4A, pp. 47-54, Nov. 1987. [Online]. doi: 10.1088/ 0143-0815/8/4A/006.

[13] T. Schlebusch, S. Nienke, S. A. Santos, and S. Leonhardt, "Bladder volume estimation from electrical impedance tomography," in 2013 35th Annual International Conference of the IEEE Engineering in Medicine and Biology Society (EMBC), 2013, vol. 35, no. 9, pp. 6441-6444. [Online]. doi: 10.1109/EMBC.2013.6611029.

[14] C. Polk and E. Postow, Handbook of Biological Effects of Electromagnetic Fields, -2 Volume Set. CRC press, 1995.

[15] M. Guermandi, R. Cardu, E. F. Scarselli, and R. Guerrieri, "Active electrode IC for EEG and electrical impedance tomography with continuous monitoring of contact impedance," IEEE Transactions on Biomedical Circuits and Systems, vol. 9, no. 1. pp. 21-33, 2015. [Online]. doi: 10.1109/TBCAS.2014.2311836.

[16] M. Soleimani, C. Gómez-Laberge, and A. Adler, "Imaging of conductivity changes and electrode movement in EIT," Physiological Measurement, vol. 27, no. 5, pp. S103-S113, May 2006. [Online]. doi: 10.1088/0967-3334/27/5/S09.

[17] D. Leonhäuser et al., "Evaluation of electrical impedance tomography for determination of urinary bladder volume: comparison with standard ultrasound methods in healthy volunteers," Biomedical engineering online, vol. 17, no. 1. BioMed Central, p. 95, 2018. [Online]. doi: 10.1186/s12938-018-0526-0.

[18] S. B. Ayati, K. Bouazza-Marouf, and D. Kerr, "In vitro localisation of intracranial haematoma using electrical impedance tomography semi-array," Medical Engineering \& Physics, vol. 37, no. 1, pp. 34-41, Jan. 2015. [Online]. doi: 10.1016/j.medengphy.2014.10.001. 
[19] O. L. Silva, R. G. Lima, T. C. Martins, F. S. de Moura, R. S. Tavares, and M. S. G. Tsuzuki, "Influence of current injection pattern and electric potential measurement strategies in electrical impedance tomography," Control Engineering Practice, vol. 58. Elsevier, pp. 276-286, 2017. [Online]. doi: 10.1016/j.conengprac.2016.03.003.

[20] E. Malone, G. Sato dos Santos, D. Holder, and S. Arridge, "Multifrequency Electrical Impedance Tomography Using Spectral Constraints," IEEE Transactions on Medical Imaging, vol. 33, no. 2, pp. 340-350, Feb. 2014. [Online]. doi: 10.1109/TMI.2013.2284966.

[21] A. Koksal and B. M. Eyuboglu, "Determination of optimum injected current patterns in electrical impedance tomography," Physiological Measurement, vol. 16, no. 3A, pp. A99-A109, Aug. 1995. [Online]. doi: 10.1088/0967-3334/16/3A/010.

[22] B. H. Brown and A. D. Seagar, "The Sheffield data collection system," Clinical Physics and Physiological Measurement, vol. 8, no. 4A, pp. 91-97, Nov. 1987. [Online]. doi: 10.1088/0143 $-0815 / 8 / 4 \mathrm{~A} / 012$.

[23] S. Leonhardt et al., "Electric impedance tomography for monitoring volume and size of the urinary bladder," Biomedizinische Technik/Biomedical Engineering, vol. 56, no. 6, pp. 301-307, Jan. 2011. [Online]. doi: 10.1515/BMT.2011.022.

[24] A. Romsauerova, A. McEwan, L. Horesh, R. Yerworth, R. H. Bayford, and D. S. Holder, "Multifrequency electrical impedance tomography (EIT) of the adult human head: initial findings in brain tumours, arteriovenous malformations and chronic stroke, development of an analysis method and calibration," Physiological Measurement, vol. 27, no. 5, pp. S147-S161, May 2006. [Online]. doi: 10.1088/0967-3334/27/5/S13.

[25] E. Santos and F. Simini, "Alternativas de proyecto e implementación de circuitos y de programas de reconstrucción tendientes a un tomógrafo por impedancia eléctrica para la presentación compacta del estado edemático de cortes torácicos en tiempo real.” p. 255, 2014.

[26] K. Petersen, S. Vakkalanka, and L. Kuzniarz, "Guidelines for conducting systematic mapping studies in software engineering: An update," Information and Software Technology, vol. 64. Elsevier, pp. 1-18, 01-Aug-2015. [Online]. doi: 10.1016/j.infsof.2015.03.007.

[27] B. Lachmann, O. L. Concept, and D. Gommers, "Respiratory Cycle in 90 Images," no. February. pp. 20-22, 2010.

[28] Dräger, "Dräger PulmoVista ${ }^{\circledR} 500$ ICU Ventilation and Respiratory Monitoring." [Online]. Available: https://www.draeger.com/Products/Content/pulmovist, 2017. 
[29] T. I. Oh, H. Koo, K. H. Lee, and S. M. Kim, "Validation of a multi-frequency electrical impedance tomography ( mfEIT ) system KHU Mark1: impedance spectroscopy and time-difference imaging," vol. 295. [Online]. doi: 10.1088/0967-3334/29/3/002.

[30] H. Wi, H. Sohal, A. L. McEwan, E. J. Woo, and T. I. Oh, "Multi-frequency electrical impedance tomography system with automatic self-calibration for long-term monitoring," IEEE Transactions on Biomedical Circuits and Systems, vol. 8, no. 1. pp. 119-128, 2014. [Online]. doi: 10.1109/TBCAS.2013.2256785.

[31] X. Yue and C. McLeod, "FPGA design and implementation for EIT data acquisition," Physiological Measurement, vol. 29, no. 10, pp. 1233-1246, Oct. 2008. [Online]. doi: 10.1088/0967-3334/29/10/007.

[32] R. J. Halter, A. Hartov, and K. D. Paulsen, "A Broadband High-Frequency Electrical Impedance Tomography System for Breast Imaging," IEEE Transactions on Biomedical Engineering, vol. 55, no. 2. IEEE, pp. 650-659, Feb-2008. [Online]. doi: 10.1109/TBME.2007.903516.

[33] S. Kimel-naor, S. Abboud, and M. Arad, "Parametric electrical impedance tomography for measuring bone mineral density in the pelvis using a computational model," Medical Engineering and Physics, vol. 0. Elsevier Ltd, pp. 1-7, 2016. [Online]. doi: 10.1016/j.medengphy.2016.04.013.

[34] S. A. Santos, A. Robens, A. Boehm, S. Leonhardt, and D. Teichmann, "Supplementary Materials: System Description and First Application of an FPGA-Based Simultaneous Multi-Frequency Electrical Impedance Tomography mfDummy Amplitude mfDummy Amplitude and Phase all same scale Selbstversuche M1," no. 5. pp. 2-4, 2016. [Online]. doi: 10.3390/s16081158.

[35] X. Shi et al., "Design and implementation of a high-precision electrical impedance tomography data acquisition system for brain imaging," in 2016 IEEE Biomedical Circuits and Systems Conference (BioCAS), 2016, pp. 9-15. [Online]. doi: 10.1109/BioCAS.2016.7833712.

[36] P. Artem and S. Dmitry, "FPGA technologies in medical equipment: Electrical impedance tomography," Proceedings of IEEE East-West Design and Test Symposium, EWDTS 2013. pp. 0-3, 2013. [Online]. doi: 10.1109/EWDTS.2013.6673157.

[37] G. Xu et al., "A 128-Electrode Three Dimensional Electrical Impedance Tomography System," in 2007 29th Annual International Conference of the IEEE Engineering in Medicine and Biology Society, 2007, pp. 4386-4389. [Online]. doi: 10.1109/IEMBS.2007.4353310. 
[38] A. Fouchard et al., "Modular architecture of a Multi - frequency Electrical Impedance Tomography system: design and implementation," 36th Annual International Conference of the IEEE Engineering in Medicince and Biology Society. pp. 6076-6079, 2014. [Online]. doi: 10.1109/EMBC.2014.6945015.

[39] J. Huang, Y. Hung, J. Wang, and B. Lin, "Design of wearable and wireless electrical impedance tomography system," MEASUREMENT, vol. 78. Elsevier Ltd, pp. 9-17, 2016. [Online]. doi: 10.1016/j.measurement.2015.09.031.

[40] M. Khalighi, B. Vosoughi Vahdat, M. Mortazavi, W. Hy, and M. Soleimani, "Practical design of low-cost instrumentation for industrial electrical impedance tomography (EIT)," 2012 IEEE I2MTC - International Instrumentation and Measurement Technology Conference, Proceedings. pp. 1259-1263, 2012. [Online]. doi: 10.1109/I2MTC.2012.6229173.

[41] V. Tomicic and R. Cornejo, "Lung monitoring with electrical impedance tomography: technical considerations and clinical applications," Journal of Thoracic Disease, vol. 11, no. 7, pp. 3122-3135, Jul. 2019. [Online]. doi: 10.21037/jtd.2019.06.27.

[42] M. Salucci and G. Oliveri, "Robust real囚time inversion of electrical impedance tomography data for human lung ventilation monitoring," Microwave and Optical Technology Letters, vol. 61, no. 1, pp. 5-8, Jan. 2019. [Online]. doi: 10.1002/mop.31501.

[43] J. N. G. Lima, M. S. Fontes, T. Szmuszkowicz, A. M. Isola, and A. T. Maciel, "Electrical impedance tomography monitoring during spontaneous breathing trial: Physiological description and potential clinical utility," Acta Anaesthesiologica Scandinavica, p. aas.13383, May 2019. [Online]. doi: 10.1111/aas.13383.

[44] B. Yang et al., "Comparison of electrical impedance tomography and intracranial pressure during dehydration treatment of cerebral edema," Neurolmage: Clinical, vol. 23, p. 101909, 2019. [Online]. doi: 10.1016/j.nicl.2019.101909.

[45] A. Everitt, B. K. Root, D. F. Bauer, and R. J. Halter, "Electrical impedance mapping for localizing evolving traumatic brain injury," in Medical Imaging 2019: Biomedical Applications in Molecular, Structural, and Functional Imaging, 2019, vol. 10953, p. 30. [Online]. doi: 10.1117/12.2512292.

[46] Y. Li et al., "Analysis of measurement electrode location in bladder urine monitoring using electrical impedance," Biomedical engineering online, vol. 18, no. 1, p. 34, 2019.

[47] Y.-J. Han, A. K. Khambampati, and K.-Y. Kim, "Performance analysis of EIT bladder monitoring system according to input current patterns," Journal of IKEEE, vol. 23, no. 1, pp. 164-172, 2019. [Online]. doi: https://doi.org/10.7471/ikeee.2019.23.1.164. 
[48] S. Arad, S. Zlochiver, and M. Mahajna, "Diagnostic and monitoring electrical impedance tomography (eit) system for osteoporosis." Google Patents, 2019.

[49] G. Hansen, T. Holt, and J. Dmytrowich, "Thoracic electrical impedance tomography to minimize right heart strain following cardiac arrest,” 2019.[Online].doi:10.4103/apc.APC_189_18.

[50] A. M. Ambrosio et al., "Ventilation distribution assessed with electrical impedance tomography and the influence of tidal volume, recruitment and positive end-expiratory pressure in isoflurane-anesthetized dogs," Veterinary Anaesthesia and Analgesia, vol. 44, no. 2, pp. 254263, Mar. 2017. [Online]. doi: 10.1016/j.vaa.2016.06.003.

[51] B. Grychtol, G. Elke, P. Meybohm, N. Weiler, I. Frerichs, and A. Adler, "Functional Validation and Comparison Framework for EIT Lung Imaging," PLoS ONE, vol. 9, no. 8, p. e103045, Aug. 2014. [Online]. doi: 10.1371/journal.pone.0103045.

[52] Doan Trang Nguyen et al., "Electrical Impedance Tomography for assessing Ventilation/ Perfusion mismatch for Pulmonary Embolism detection without interruptions in respiration," 2014 36th Annual International Conference of the IEEE Engineering in Medicine and Biology Society. IEEE, pp. 6068-6071, Aug-2014. [Online]. doi: 10.1109/EMBC.2014.6945013.

[53] K. Roubik, V. Sobota, and M. Laviola, "Selection of the Baseline Frame for Evaluation of Electrical Impedance Tomography of the Lungs," in 2015 Second International Conference on Mathematics and Computers in Sciences and in Industry (MCSI), 2015, pp. 293-297. [Online]. doi: 10.1109/MCSI.2015.51.

[54] A. D. Waldmann et al., "Position-dependent distribution of lung ventilation \&amp;\#x2014; A feasability study," in 2015 IEEE Sensors Applications Symposium (SAS), 2015, pp. 1-6. [Online]. doi: 10.1109/SAS.2015.7133643.

[55] C. J. C. Trepte et al., "Electrical impedance tomography (EIT) for quantification of pulmonary edema in acute lung injury," Critical Care, vol. 20, no. 1, p. 18, Dec. 2015. [Online]. doi: 10.1186/ s13054-015-1173-5.

[56] L. Andiani, A. Rubiyanto, and Endarko, "Sensitivity analysis of thorax imaging using two-dimensional Electrical Impedance Tomography (EIT)," Journal of Physics: Conference Series, vol. 1248, no. 1, 2019. [Online]. doi: 10.1088/1742-6596/1248/1/012009.

[57] J. Bordes, P. Goutorbe, P. J. Cungi, M. C. Boghossian, and E. Kaiser, "Noninvasive ventilation during spontaneous breathing anesthesia: an observational study using electrical impedance tomography," Journal of Clinical Anesthesia, vol. 34, pp. 420-426, Nov. 2016. [Online]. doi:10.1016/j.jclinane.2016.04.016. 
[58] J. L. Hough, A. D. Shearman, H. Liley, C. A. Grant, and A. Schibler, "Lung recruitment and endotracheal suction in ventilated preterm infants measured with electrical impedance tomography," Journal of Paediatrics and Child Health, vol. 50, no. 11, pp. 884-889, Nov. 2014. [Online]. doi:10.1111/jpc.12661.

[59] F. Trenk et al., "Evaluation of lung ventilation distribution in chronic obstructive pulmonary disease patients using the global inhomogeneity index," in 2016 38th Annual International Conference of the IEEE Engineering in Medicine and Biology Society (EMBC), 2016, pp. 52865289. [Online]. doi: 10.1109/EMBC.2016.7591920.

[60] S. Heizmann, M. Baumgärtner, S. Krüger-Ziolek, Z. Zhao, and K. Möller, "3-D Lung Visualization Using Electrical Impedance Tomography Combined with Body Plethysmography," in The 15th International Conference on Biomedical Engineering, 2014, pp. 172-175. [Online]. doi: 10.1007/978-3-319-02913-9_44.

[61] I. Chatziioannidis, T. Samaras, G. Mitsiakos, P. Karagianni, and N. Nikolaidis, "Assessment of lung ventilation in infants with respiratory distress syndrome using electrical impedance tomography," Hippokratia, vol. 17, no. 2. Hippokratio General Hospital of Thessaloniki, p. 115, 2013.

[62] F. Rossi, A. Yagui, L. Haddad, A. Deutsch, and C. Rebello, "Electrical impedance tomography to evaluate air distribution prior to extubation in very-low-birth-weight infants: a feasibility study," Clinics, vol. 68, no. 3, pp. 345-350, Mar. 2013. [Online]. doi: 10.6061/clinics/2013(03) OA10.

[63] B. Amm et al., "Real-time 3D electrical impedance imaging for ventilation monitoring of the lung: Pilot study," in 2014 36th Annual International Conference of the IEEE Engineering in Medicine and Biology Society,2014, pp.6064-6067. [Online]. doi: 10.1109/EMBC.2014.6945012.

[64] M. Balleza-Ordaz, E. Perez-Alday, M. Vargas-Luna, and J. P. Riu, "Tidal volume monitoring by electrical impedance tomography (EIT) using different regions of interest (ROI): Calibration equations," Biomedical Signal Processing and Control, vol. 18, pp. 102-109, Apr. 2015. DOI:10.1016/j.bspc.2014.12.004.

[65] K. Buzkova and J. Suchomel, "Use of electrical impedance tomography for quantitative evaluation of disability level of bronchopulmonary dysplasia," in 2013 E-Health and Bioengineering Conference (EHB), 2013, pp. 1-4. [Online]. doi: 10.1109/EHB.2013.6707307. 
[66] S. Hong, J. Lee, J. Bae, and H. Yoo, "A 10.4 mW electrical impedance tomography SoC for portable real-time lung ventilation monitoring system," in 2014 IEEE Asian Solid-State Circuits Conference (A-SSCC), 2014, vol. 50, no. 11, pp. 193-196. [Online]. doi:10.1109/ ASSCC.2014.7008893.

[67] M. Kim, J. Bae, and H.-J. Yoo, "Wearable 3D lung ventilation monitoring system with multi frequency electrical impedance tomography," in 2017 IEEE Biomedical Circuits and Systems Conference (BioCAS), 2017, pp. 1-4. [Online]. doi: 10.1109/BIOCAS.2017.8325163.

[68] J. Lee, U. Ha, and H. Yoo, "30-fps SNR equalized electrical impedance tomography IC with fast-settle filter and adaptive current control for lung monitoring," in 2016 IEEE International Symposium on Circuits and Systems (ISCAS), 2016, vol. c, pp. 109-112. [Online]. doi: 10.1109/ ISCAS.2016.7527182.

[69] N. Omer, S. Abboud, and M. Arad, "Classifying lung congestion in congestive heart failure using electrical impedance - a 3D model," in 2015 Computing in Cardiology Conference (CinC), 2015, pp. 369-372. [Online]. doi: 10.1109/CIC.2015.7408663.

[70] Zhanqi Zhao, K. Moller, B. Vogt, I. Frerichs, and U. Muller-Lisse, "Customized evaluation software for clinical trials: An example on pulmonary function test with electrical impedance tomography," in 2013 ICME International Conference on Complex Medical Engineering, 2013, pp. 128-133. [Online]. doi: 10.1109/ICCME.2013.6548225.

[71] S. Ren, K. Sun, D. Liu, and F. Dong, "A Statistical Shape Constrained Reconstruction Framework for Electrical Impedance Tomography," IEEE Transactions on Medical Imaging, no. 1, pp. 1-1, 2019. [Online]. doi: 10.1109/tmi.2019.2900031.

[72] J. Latikka and H. Eskola, "The Resistivity of Human Brain Tumours In Vivo," Annals of Biomedical Engineering, vol. 47, no. 3, pp. 706-713, 2019. [Online]. doi: 10.1007/s10439-018-02189-7.

[73] B. Yang et al., "Real-time imaging of cerebral infarction in rabbits using electrical impedance tomography," Journal of International Medical Research, vol. 42, no. 1, pp. 173-183, Feb. 2014. [Online]. doi: 10.1177/0300060513499100.

[74] J. Gao, S. Yue, J. Chen, and H. Wang, "Classification of normal and cancerous lung tissues by electrical impendence tomography," Bio-medical materials and engineering, vol. 24, no. 6. IOS press, pp. 2229-2241, 2014. [Online]. doi: 10.3233/BME-141035. 
[75] J. Sola, M. Proenca, and O. Chetelat, "Wearable PWV technologies to measure Blood Pressure: eliminating brachial cuffs," in 2013 35th Annual International Conference of the IEEE Engineering in Medicine and Biology Society (EMBC), 2013, pp. 4098-4101. [Online]. doi: 10.1109/EMBC.2013.6610446.

[76] J. Solà, A. Adler, A. Santos, G. Tusman, F. Suárez Sipmann, and S. H. Bohm, "Unsupervised non-invasive measurement of aortic pulse transit time by means of electrical impedance tomography," Artery Research, vol. 5, no. 4, p. 144, Dec. 2011. [Online]. doi: 10.1016/j. artres.2011.10.225.

[77] J. Solà, A. Adler, A. Santos, G. Tusman, F. S. Sipmann, and S. H. Bohm, "Non-invasive monitoring of central blood pressure by electrical impedance tomography: first experimental evidence," Medical \& Biological Engineering \& Computing, vol. 49, no. 4, pp. 409-415, Apr. 2011. [Online]. doi: 10.1007/s11517-011-0753-z.

[78] S. Leonhardt, R. Pikkemaat, O. Stenqvist, and S. Lundin, "Electrical Impedance Tomography for hemodynamic monitoring," in 2012 Annual International Conference of the IEEE Engineering in Medicine and Biology Society, 2012, pp. 122-125. [Online]. doi: 10.1109/EMBC.2012.6345886.

[79] D. Chakraborty and M. Chattopadhyay, "Finite Element Method based Modeling of a Sensory System for Detection of Atherosclerosis in Human Using Electrical Impedance Tomography," Procedia Technology, vol. 10, pp. 262-270, 2013. [Online]. doi: 10.1016/j.protcy.2013.12.360.

[80] M. Proença, F. Braun, J. Solà, J.-P. Thiran, and M. Lemay, "Noninvasive pulmonary artery pressure monitoring by EIT: a model-based feasibility study," Medical \& Biological Engineering \& Computing, vol. 55, no. 6, pp. 949-963, Jun. 2017. [Online]. doi: 10.1007/s11517-016-1570-1.

[81] F. Fu et al., "Use of Electrical Impedance Tomography to Monitor Regional Cerebral Edema during Clinical Dehydration Treatment," PLOS ONE, vol. 9, no. 12, p. e113202, Dec. 2014. [Online]. doi: 10.1371/journal.pone.0113202.

[82] M. Dai et al., "In Vivo Imaging of Twist Drill Drainage for Subdural Hematoma: A Clinical Feasibility Study on Electrical Impedance Tomography for Measuring Intracranial Bleeding in Humans," PLoS ONE, vol. 8, no. 1, p. e55020, Jan. 2013. [Online]. doi: 10.1371/journal. pone.0055020.

[83] G. Boverman, T.-J. Kao, X. Wang, J. M. Ashe, D. M. Davenport, and B. C. Amm, "Detection of small bleeds in the brain with electrical impedance tomography," Physiological Measurement, vol. 37, no. 6, pp. 727-750, Jun. 2016. [Online]. doi: 10.1088/0967-3334/37/6/727. 
[84] S. Suksawang, K. Niamsri, and T. Ouypornkochagorn, "Scalp Voltage Response to Conductivity Changes in," 2018 15th International Conference on Electrical Engineering/Electronics, Computer, Telecommunications and Information Technology (ECTI-CON), no. July, pp. 223236, 2018.

[85] S. R. Atefi, F. Seoane, S. Kamalian, E. S. Rosenthal, M. H. Lev, and G. Bonmassar, "Intracranial hemorrhage alters scalp potential distribution in bioimpedance cerebral monitoring: Preliminary results from FEM simulation on a realistic head model and human subjects," Medical Physics, vol. 43, no. 2, pp. 675-686, Jan. 2016. [Online]. doi: 10.1118/1.4939256.

[86] R. Li, J. Gao, Y. Li, J. Wu, and Z. Zhao, "Preliminary Study of Assessing Bladder Urinary Volume Using Electrical Impedance Tomography," Journal of Medical and Biological Engineering, vol. 36, no. 1. Springer Berlin Heidelberg, pp. 71-79,2016. [Online]. doi:10.1007/s40846-016-0108-1.

[87] T. Schlebusch et al., "Impedance ratio method for urine conductivity-invariant estimation of bladder volume," Journal of Electrical Bioimpedance, vol. 5, no. 1, pp. 48-54, Sep. 2014. [Online]. doi: 10.5617/jeb.895.

[88] T. Schlebusch and S. Leonhardt, "Effect of electrode arrangements on bladder volume estimation by electrical impedance tomography," Journal of Physics: Conference Series, vol. 434, no. 1. 2013. [Online]. doi: 10.1088/1742-6596/434/1/012080.

[89] A. Ron, S. Abboud, and M. Arad, "Home monitoring of bone density in the wrist-a parametric EIT computer modeling study," Biomedical Physics \& Engineering Express, vol. 2, no. 3, p. 035002, Apr. 2016. [Online]. doi: 10.1088/2057-1976/2/3/035002.

[90] A. Nishida et al., "A new method for the estimation of age at death by using electrical impedance: A preliminary study," Legal Medicine, vol. 17, no. 6, pp. 560-568, Nov. 2015. [Online]. doi: 10.1016/j.legalmed.2015.07.003.

[91] Y. Zeng, L. Xu, Z. Cao, and S. Ma, "FPGA-based implementation of Prony demodulation in the multi-frequency EIT system," Conference Record - IEEE Instrumentation and Measurement Technology Conference, pp. 548-552, 2011. [Online]. doi: 10.1109/IMTC.2011.5944251.

[92] T. K. Bera and J. Nagaraju, "Studying the surface electrode switching of a sixteen electrode EIT system using a LabVIEW-based electrode switching module (LV-ESM)," in International Conference on Circuits, Communication, Control and Computing, 2014, no. November, pp. 122-127. [Online]. doi: 10.1109/CIMCA.2014.7057772. 
[93] S. Ping and H. Jiang, "Design of electrical Impedance Tomography system based on layer stripping process,” vol. 329. pp. 392-396, 2013. [Online]. doi: 10.4028/www.scientific.net/ AMM.329.392.

[94] P. O. Gaggero, A. Adler, J. Brunner, and P. Seitz, "Electrical impedance tomography system based on active electrodes," vol. 831. 2012. [Online]. doi: 10.1088/0967-3334/33/5/831.

[95] J. Bordes, C. Mazzeo, P. Goutorbe, K. Wade, and E. Kaiser, "Visualisation des variations du volume pulmonaire de fin d'expiration au cours d'une anesth\{é\}sie g\{é\}n\{é\}rale par tomographie d'imp\{é\}dance \{é\}lectrique," Annales Fran\{ç\}aises d'Anesth\{é\}sie et de R\{é\}animation, vol. 33, no. 3. pp. 193-195, 2014.

[96] M. Guermandi, R. Cardu, E. Franchi, and R. Guerrieri, "Active electrode IC combining EEG, electrical impedance tomography, continuous contact impedance measurement and power supply on a single wire," European Solid-State Circuits Conference. pp. 335-338, 2011. [Online]. doi: 10.1109/ESSCIRC.2011.6044975.

[97] J. S. Isaac and R. Kulkarni, "Super resolution techniques for medical image processing," in 2015 International Conference on Technologies for Sustainable Development (ICTSD), 2015, pp. 1-6. [Online]. doi: 10.1109/ICTSD.2015.7095900.

[98] M. Khalighi, B. Vosoughi Vahdat, M. Mortazavi, and A. M. Mikaeili, "Design and Implementation of Precise Hardware for Electrical Impedance Tomography (Eit)," Transactions of Electrical Engineering, vol. 38, no. E1. pp. 1-20, 2014. [Online]. doi: 10.1007/s00101-007-1273-y.

[99] H. Fujita et al., "Medical image processing and computer-aided detection/diagnosis (CAD)," Computerized Healthcare (ICCH), 2012 International Conference on. pp. 66-71, 2012. [Online]. doi: 10.1109/ICCH.2012.6724473.

[100] Hun Wi, H. Sohal, A. L. McEwan, Eung Je Woo, and Tong In Oh, "Multi-Frequency Electrical Impedance Tomography System With Automatic Self-Calibration for Long-Term Monitoring," IEEE Transactions on Biomedical Circuits and Systems, vol. 8, no. 1, pp. 119-128, Feb. 2014. [Online]. doi: 10.1109/TBCAS.2013.2256785.

[101]A. McEwan, G. Cusick, and D. S. Holder, "A review of errors in multi-frequency EIT instrumentation," Physiological Measurement, vol. 28, no. 7, pp. S197-S215, Jul. 2007. [Online]. doi: 10.1088/0967-3334/28/7/S15. 
[102] O. Luppi Silva, R. Gonzalez Lima, T. Castro Martins, F. Silva de Moura, R. Seiji Tavares, and M. Sales Guerra Tsuzuki, "Influence of current injection pattern and electric potential measurement strategies in electrical impedance tomography," Control Engineering Practice. Elsevier, pp. 1-11, 2016. [Online]. doi: 10.1016/j.conengprac.2016.03.003.

[103] S. Khan, A. Borsic, P. Manwaring, A. Hartov, and R. Halter, "FPGA Based High Speed Data Acquisition System for Electrical Impedance Tomography.," Journal of physics. Conference series, vol. 434, no. 1. p. 012081, 2013. [Online]. doi: 10.1088/1742-6596/434/1/012081.

[104]Z. Zhang, F. Dong, and C. Xu, "Data acquisition system based on CompactPCI bus and FPGA for electrical resistance tomography," in 2011 Chinese Control and Decision Conference (CCDC), 2011, pp. 3538-3543. [Online]. doi: 10.1109/CCDC.2011.5968731.

[105] H. Wi, H. Sohal, A. L. McEwan, E. J. Woo, and T. I. Oh, "Multi-frequency electrical impedance tomography system with automatic self-calibration for long-term monitoring," IEEE Transactions on Biomedical Circuits and Systems, vol. 8, no. 1, pp. 119-128, 2014. [Online]. doi:10.1109/TBCAS.2013.2256785.

[106] I. Kukharenko and V. Kotovskyi, "Low power bioimpedance tracking system for stress and activity monitoring," in 2017 IEEE 37th International Conference on Electronics and Nanotechnology (ELNANO), 2017, pp. 288-291. [Online]. doi: 10.1109/ELNANO.2017.7939764.

[107]V. Chitturi and N. Farrukh, "A Low Cost Electrical Impedance Tomography ( EIT ) for Pulmonary Disease Modelling and Diagnosis .," Name: The Second International Conference on Technological Advances in Electrical, Electronics and Computer Engineering (TAEECE2014), no. March 2014, pp. 83-89, 2014. 